\title{
Constitutional Jurisdiction (Judicial) Proceeding as a Means of Security and Defense of the Bases of Constitutional System of Russia
}

\author{
Svetlana Antonovna Savchenko \\ Doctor of Legal Sciences, Professor, Tyumen State University, Russian Federation \\ Email: prepod72@bk.ru
}

Doi:10.5901/mjss.2015.v6n1s2p78

\begin{abstract}
Judicial defense is the major legal guarantee of a legality principle, because exactly a court settles the question put before it about the breach of law, and restores the violated rights. Judicial defense is a type of legal defense. The judicial defense from illegal decisions, actions (inactions) of legislative (representative) and executive bodies of state power is executed by the Federal courts (Constitutional Court of the Russian Federation, courts of general jurisdiction, arbitration courts) and constitutional (statutory) courts of the Russian Federation subjects. The Constitutional Court of the Russian Federation is one of branches of judicial power that performs the functions in the forms of the constitutional legal proceeding provided by the law. On the stage of summing up of execution of the investment and social tasks in the Russian Federation the balance of interests (public and private) of the contracting parties is observed and the one-sided estimation of the real results is eliminated.
\end{abstract}

Keywords: judicial defense, constitutional control, Constitution, judicial trial, Constitutional Court.

\section{Introduction}

Judicial defense is the major legal guarantee of a legality principle, because exactly a court settles the question put before it about the breach of law, and restores the violated rights. The basis of any science is made by a notion-category apparatus. With its help the process of cognition of existential laws and development of the concrete reality (Avtonomov, 1999) is carried out, therefore the subject of research included determination of the notion "judicial defense". Judicial defense is a type of legal defense. Norms about right defense of are present in all industries, however neither of them fixes notion of rights defense. A large explanatory dictionary determines «legal defense» as a defense, and assertion of human rights (Big Explanatory Dictionary of the Russian Language, 2000). In a legal encyclopedia the «defense» is considered as a complex system of measures, applied for providing of free and proper implementation of equitable rights, including judicial defense, legislative, economic, organizational-technical and other facilities and measures, as well as self-defense of the civil rights (Tikhomirova, 2001). In legal literature there is no exact determination of the considered notion. Many utterances on this question are reduced to judgements about influence on the right violated and disputed. In addition, giving determination of the right defense, the authors variously understand this content, depending on that, what question is formulated by them (in what moment a right needs defense, in what forms and what methods). They understand under the right defense an activity of the authorized person or authorized state or public bodies on application to the distributors of the legal defense measures of the state-forced character (measures of responsibility or measures of defense), directed on confession or renewal of the subjective civil right disputed or violated (Shevchenko, 1990). Other consider legal defense to be the state-forced activity, directed on renewal of the violated right, providing of execution of legal duty (Alekseev, 1994). The state defense of rights and freedoms is activity of authorized bodies and officials on the observance, provision and defense of the constitutional rights and freedoms (Constitutional right of the Russia, 2001). It follows from the resulted interpretations of this notion, that legal defense supposes renewal of the violated right and wide spectrum of the legal mechanisms of defending legal interests of different subjects. The legislative determination of «legal defense» of legal entities and natural persons from illegal actions of the legislative (representative) and executive authorities of the state power is absent. On the assumption of existent interpretations, it is possible to formulate: legal defense from the illegal decisions, actions (inactions) the legislative (representative) and executive authorities of the state power is the aggregate of the means and methods of defending the rights and legal interests of the legal entities and natural persons directed on renewal of the violated right and its unimpeded realization set by a law. 


\section{Main Text}

Within the framework of state defense the judicial and extra-judicial guarantees are selected. The judicial defense is a type of legal defense. Constitution of the Russian Federation considers judicial defense as a part of the system of means and bodies of the legal provision of observance of citizens' rights and freedoms acting in a country. The right of judicial defense is unity of material content and judicial form.

According to the material content it includes the following elements: 1) possibility of authorized person to use means of own forced influence permitted by the law on an law-breaker (self-defense of civil laws); 2) possibility of application of the legal measures of operative influence on the law-breaker directly by the authorized person; 3) possibility of the authorized person to appeal to the authorized state or public bodies with the requirement of forcing of the liable to the certain conduct.

The action form of right defense includes: 1) possibility of the authorized person to appeal with the requirements about defense of the right or interest violated or disputed or guarded by a law to the competent authority in a lawsuit or the other form provided by the law; 2) possibility to use all rights and guarantees provided by the law in the process of consideration of this requirement set in application to this form of right defense; 3) possibility of appeal, and protest of decision of the body on this deed in the order provided by the law that appears to wrong for the declarant (Gribanov, 2000).

The judicial defense from illegal decisions, actions (inactions) of legislative (representative) and executive bodies of state power is executed by the Federal courts (Constitutional Court of the Russian Federation, courts of general jurisdiction, arbitration courts) and constitutional (statutory) courts of the Russian Federation subjects.

The constitutional control is a specific function of the competent state authorities on provision of the constitutional legality, supremacy of the Constitution in the system of normative acts, its direct immediate action. It has the following tasks: verification, exposure, removal of the discrepancies of normative acts of the Constitution; participation in permission of the disputable issues having the constitutional value; participation in development and perfection of legislation.

The federal body of constitutional control without assistance and independently performing the judicial power by means of the constitutional production is the Constitutional Court of the Russian Federation. It carries out verification of the normative acts of subjects of the Russian Federation within the framework of implementation of the constitutional control.

The Constitutional Court of the Russian Federation is one of branches of judicial power that performs the functions in the forms of the constitutional legal proceeding provided by the law. The legal proceeding is the variety of law-making process with the use of separate elements of judicial procedure. A legislator delegated some its functions to Constitutional Court: the right for interpretation of Constitution, acknowledgement of the legislative acts and norms, which do not correspond to the Constitution, authority to deprive the separate acts and legislative norms and etc. of the legal force. On the assumption of the peculiarities of jurisdiction, tasks and functions the Federal Constitutional Law «On Constitutional Court of the Russian Federation» and Regulation of the Constitutional Court of Russian Federation the common rules of production (section 2) and peculiarities of production on the separate categories of deeds were set (section 3).

A law «On the Constitutional Court of Russian Federation» contains two non-coinciding groups of the basic provisions: basic principles of activity and principles of the constitutional legal proceeding (item 5 of chapter1).

A law names independence, collective nature, publicity, competitiveness and equality of rights of parties to be the basic principles of activity of the Constitutional Court of the Russian Federation. The principles the legal proceeding include: the verbal nature of a trial (item 32), language of the constitutional legal proceeding (item 33), continuity of the judicial meeting (item 34). This list of principles of the Constitutional Court exposes absence of principle of legality, presumptions of innocence, participation of representatives of nation and etc. The reason can be that the Constitutional Court does not execute justice on concrete civil and criminal cases. The function of participation in the Court of accused and defendants is thus eliminated, their defenders and representatives, plaintiffs and defendants. However, the separate citizens can take part in the constitutional legal proceeding, if they appealed to the Constitutional Court with a complaint on violation of the constitutional rights and freedoms, when to their case proceeded in the proper court, the law is applied or can be applied that contradicts to the Constitution.

The constitutional legal proceeding differs from the contiguous legal proceedings by the following way: collective nature in the Constitutional Court has a feature in connection with the judicial representative office of persons, who appeal in the Constitutional Court of the Russian Federation, because the case settled by Court requires profound legal knowledge and high professionalism (Comment to the legislation about judicial power in the Russian Federation, 2000). 
Case consideration in the Court can take place only in collective composition. The quorum at the decision-making makes no less than two third from the common number of judges (taking into account the changes in FCL of the Russian Federation from 28.12.2011). The principle of independence is fastened in the item 120 of Constitution and consists in that the judges of Constitutional Court of the Russian Federation are guided in the activity only by the Constitution and Federal Constitutional Law «On Constitutional Court of the Russian Federation», come forward in the personal quality and do not represent any non-state or public bodies, parties, movements, state and territorial establishments, nations and social groups.

The verbal nature of judicial trial means that during consideration of the case of Constitutional Court of the Russian Federation explanations of the parties, testimonies of experts and witnesses are heard and documents available are announced.

Continuity of the trial means that before making a decision on case, considered in the proceeding, the Court cannot consider other cases in the proceeding.

The high degree of quality in the selection of cases subjected to consideration is the feature of the constitutional legal proceeding (process). The proper subjects of appeal in the Constitutional Court, unlike the civil, arbitration and administrative legal proceeding, can be the only those ones adopted in the Constitution of Russian Federation.

The President of Russian Federation, Federation Council, State Duma, delegates' group, making the one fifths members of the Federation Council or deputies of the State Duma, the Government of Russian Federation, as well as legislative and executive authorities of the subjects of Russian Federation can appeal with the claim about verification of constitutional nature indicated in the item 125 of the Constitution of laws, normative acts of state power and agreements. The article 96 of the Federal Constitutional Law «On Constitutional Court of the Russian Federation» provides the right to citizens, whose rights and freedoms were violated, to appeal to the Court with an individual or collective complaint. The appeal in the Constitutional Court enables to affect the future change of laws, imperfection of which will be exposed in judicial practice. It allows examining the legal proceeding in the Constitutional Court of Russian Federation as an important factor for providing of supremacy of the Constitution and strengthening of the legal order. Constitutional Court of the Russian Federation as a constitutional control body is the only state body which has the right to give interpretation of Constitution provisions. The circle of officials, having the right to the appeal in Constitutional Court with the claim about Constitution interpretation, is definitely determined and the Constitutional court is enabled to interpret norms of Constitution without corresponding appeal.

In Constitution the role of Constitutional Court of the Russian Federation in the procedure of renunciation from the position of President of the Russian Federation was determined: the Constitutional Court gives conclusion only about observance of the set order of advancement of accusation in high treason or commitment of the other severe crime. The signs of crime elements are contained in the item 15 and item 275 of CC of the Russian Federation.

The Federal Constitutional Law «On Constitutional Court of the Russian Federation» defines the basic authorities of the Constitutional Court on settlement of cases, related to its jurisdiction (item 125). These authorities are implemented by the Constitutional Court in five basic procedures: 1) settlement of cases about conformity of the Constitution of federal laws, normative acts of state bodies, agreements between them, and also international agreements which still didn't come into effect in the Russian Federation; 2) verifications of constitutional nature of the law applied or subjected to application in the concrete case, on complaints about violation of constitutional rights and freedoms of citizens and on inquiries of the courts; 3) settlement of disputes about jurisdiction; 4) official interpretation of the Constitution; 5) providing of the conclusion about the observance of the set order of accusation advancement of the President of Russian Federation in high treason or commitment of the other severe crime. The peculiarity of the constitutional legal proceeding on these procedures of the Constitutional Court is differed by the subject composition and equal judicial rights.

The decision of the Constitutional Court, mainly claim about observance of the set order for advancement of accusation by the President of Russian Federation in high treason or commitment of the other severe crime is named conclusion. The final decision of Court is made in the closed meeting and named resolution. The resolution, accepted both in meeting, and in meeting of the chambers of Court, is the resolution of Constitutional Court. The resolution of Constitutional Court operates directly and does not require confirmation by other bodies and officials.

The acts and their separate provisions acknowledged as non-constitutional ones, lose their validity. The Constitutions acknowledged as non-corresponding, and international agreement, which didn't come into effect are not subjected to giving effect and application. The resolutions of courts and other bodies, based upon the acts, acknowledge as non-constitutional, are not subjected to execution and must be reconsidered in the cases established by the federal law.

The authorities of the Constitutional Court of Russian Federation about acknowledgement of one or other legal act as the constitutional one are limited (unlike foreign countries) in a number of terms: 
a) the list of the acts, considered by the Constitutional Court of Russian Federation for the subject of conformity of the Constitution of Russia is limited and strictly fastened in the item 125;

b) consideration of the deeds by the Constitutional Court of Russian Federation about conformity to the Basic law cannot be produced at discretion and initiative of the Constitutional Court. For this purpose the request of state bodies and officials, listed in the item 125 of Constitution of the Russian Federation and other federal laws is needed.

In accordance with the Federal Constitutional Law «On Constitutional Court of the Russian Federation» (Collection of Legislative Acts of the Russian Federation, 1994) (item 3) the Constitutional Court settles cases about conformity of the Constitution of Russian Federation, constitutions of republics, regulations, as well as laws and other normative acts of the subjects of Russian Federation, published on the questions related to the administration of the public authorities to the Russian Federation and joint administration. Consideration of statements about legality of constitutions and regulations of the subjects of Russian Federation belongs to the exceptional jurisdiction of Constitutional Court. As justly marked in Resolution of Supreme Court Plenum of the Russian Federation from 29th of November in 2007 under No. 48 On practice of court consideration of the cases about contesting normative legal acts completely or partially, contestation of the named acts outside the jurisdiction to the courts of general jurisdiction, as verification of accordance of the constituent document is attended with the establishment of its accordance to the norms of Constitution of the Russian Federation.

Execution of the control over legality of normative legal acts of the subjects of Russian Federation, the Constitutional Court of Russian Federation checked up the constitutional nature of acts regulative the next spheres of public relations:

1) bases of constitutional system (state sovereignty of republics-members of the Russian Federation, property right of the subjects of Federation on the natural resources) (Collection of Legislative Acts of the Russian Federation, 2000);

2) human and civil rights and freedoms (Collection of Legislative Acts of the Russian Federation, 1997);

3) organization and activity of state authorities of the subjects of Russian Federation and local government authorities (Collection of Legislative Acts of the Russian Federation, 1997);

4) court system.

In foreign countries the constitutional control is executed not only by the constitutional courts but also by the other judicial and quasi-judicial bodies. The model of constitutional control is used by all courts of general jurisdiction in the USA, Argentina, Mexico, Denmark, Norway, Canada, Australia, India, and Japan. Large influence on its formation was made by the Anglo-Saxon system of law. However, in Great Britain the courts do not execute the similar activity because of the lack of legal difference of the basic and non-basic laws, and also partly upon the reason of dominating conception of supremacy of parliament.

Also this model is determined as decentralized, or American one, because the question about constitutional nature of law or other normative act can be put by any court, although the final decision is taken by the higher judicial jurisdiction. The specificity of procedure of this type of constitutional control lies in the unconstitutional nature of the applied law is set at consideration of the concrete criminal, civil or other cases. The court accepts resolution on the basis of statement submitted from any party about unconstitutional nature of the applied law in a concrete situation. Resolution of the court can be appealed in court of superior jurisdiction, up to a supreme court. Such practice of the constitutional control is used in the USA and Canada.

In the USA the supreme courts of the states are the superior jurisdiction in relation to the laws of the states, and the Supreme Court of the USA in regard to the federal laws. Presently the Supreme Court of the USA consists of nine judges, which are appointed by the President for the term of life upon consent of the Senate. It means that the candidature offered by the President must be is approved by two third of voices of the present senators.

The Constitution of Japan (item 81) contains the following order: «The Supreme Court is the court of superior jurisdiction, authorized to decide a question about constitutional nature of any law, decree, order or other official act». Therefore, the appeal in a court concerning unconstitutional nature of that or other legal act is accompanied by preparation of the special lawsuit. In India only the Supreme Court can take decision about constitutional or unconstitutional nature of laws, while courts of inferior jurisdiction do not possess such authorities. In this model the subsequent constitutional control is used, when the laws, which were adopted and became valid, are subjected to verification on the constitutional nature.

The body executing the constitutional supervision can acknowledge the whole law or its separate provision as contradicting to the constitution. However, the Supreme Court makes the final decision in the form of establishment of the constitutional or unconstitutional nature of the law. It cannot conceal this law. The law, acknowledged as unconstitutional 
one, remains in collections of laws, but neither court, nor other state bodies must not to apply it. The publication of information about constitutional or unconstitutional nature of the law is the obligatory condition of the form of constitutional control. The state bodies are informed about the attitude of different social groups to this problem (Skubchenko, 2000).

Other model of constitutional control is used in those countries, where for this purpose the special judicial bodies which are not included in the system of courts of general jurisdiction are created, that allows the range of authors to name it centralized. The Constitutional Court is the special body, which only or basic function is execution of the constitutional control.

First this institute was founded in Austria in 1920 and received wide distribution in Western and Eastern Europe, and also in some countries of Asia, Africa and America. Unlike the Supreme Courts, the Constitutional Court is not included in the system of courts of general jurisdiction.

In Russia it is considered to be the court of the special category included in the judicial system, in Germany, Italy, Romania, and Mongolia - the special body of control, related to judicial power. The specificity of procedure of this type of constitutional control lies in that it can be incited upon the initiative of the subjects of constitutional supervision set by the law. Mainly the meetings of constitutional courts are conducted on principles of civil procedure, although recently the problems of special constitutional process, where judge-speaker and experts are attracted and proofs are evaluated are developed more frequently (Chirkin, 2001).

Verification of legality of the normative legal acts of subjects of the Russian Federation is executed by the federal courts of general jurisdiction, upon guidance of the subsection III «Proceeding on cases, arising from the public legal relation" of section II of the Civil Procedural Code of the Russian Federation. In accordance with item 251 the right for claim submission about contesting of the normative legal acts belongs to:

1) a citizen, or organization, which consider that the normative legal act of state authority, local self-government body or official accepted and published in accordance with established procedure their violated their rights and freedoms, assured by the Constitution of Russian Federation, laws and other normative legal acts;

2) prosecutor within its jurisdiction;

3) The President of Russian Federation, the Government of Russian Federation, legislative (representative) body of the subject of Russian Federation, superior official of the subject of Russian Federation, local selfgovernment body, and the head of municipal establishment, which consider the normative legal act accepted and published in accordance with established procedure violated their jurisdiction.

The courts of general jurisdiction, verifying the accordance of normative legal act to the requirements of current law, check up not only material, but also judicial norms, as well as the rules of legal method, namely: authorities of a body for issuing the law and its limits; form (kind) in which the body, and superior are entitled to adopt normative acts; the rules of implementation of the normative legal acts provided in action (including the rules of their publication).

In addition, the court obligatory finds out, whether the substantial provisions of the normative act regulating the procedure of its adoption were observed.

The federal legislation set «overcentralization» on the federal level of adjusting of the articles of joint administration, as a result completeness of state power of the subjects of Russian Federation assured by the Constitution of Russian Federation is out of the jurisdiction of the Russian Federation, their legal freedom on the subjects of joint administration turns out to be fiction (for example, authorities of the subject in the area of local self-government). As a result the separate violations of federal legal norms in the system of regional legislation take place.

The structural changes in the economic relations of the majority of states in the modern world, democratization of the political systems on post-Soviet space, powerful changes in an ideological area, acknowledgement of the absolute value of human personality, its rights and freedoms stipulated the important changes in the Russian procedural law.

\section{Conclusions}

The resolutions of the Constitutional Court of Russian Federation play the peculiar role in formation of the economic system of Russia.

In accordance with the item 217 of the Civil code of Russian Federation the property found in public or municipal possession can be passed in the ownership of citizens and the legal entities in the manner provided by the law on privatization. In the Federal law from the 21st July in 1997 «On privatization of the state property and the bases of privatization of municipal property in the Russian Federation" (Collection of Legislative Acts of the Russian Federation, 1997) the legislator thought as possible to bound equally such "transformation of the proprietary relations" with the purposes of increase of economical effectiveness, and its social orientation. The request of the Supreme Arbitration Court of Russian Federation to the Constitutional Court of Russian Federation became the specific confirmation of incapability 
of such combination. In the resolution taken about the deed from the 25th July in 2001 (Collection of Legislative Acts of the Russian Federation, 2001) the Constitutional Court of Russian Federation related persons, which receive property in the privatization process of state and municipal property, to the number of legal holders, who execute their rights along with the private owners.

Summarizing and highly evaluating the peculiar role of resolutions of the Constitutional Court of Russian Federation, we can expect that on the stage of summing up of execution of the investment and social tasks in the Russian Federation the balance of interests (public and private) of the contracting parties is observed and the one-sided estimation of the real results is eliminated.

\section{References}

Alekseev, S. S. (1994). The theory of right. Moscow : BEK,.

Avtonomov, A. S. (1999). Legal anthology of policy to construction of the category system. Moscow: Inforgraf.

Big Explanatory Dictionary of the Russian Language. (2000). Edited by Kuznetsov. Saint-Petersburg: Porint.

Chirkin, V. E. (2001). Constitutional right of the foreign counties. Moscow: Yurist.

Collection of Legislative Acts of the Russian Federation. (1994). Moscow: Law.

Collection of Legislative Acts of the Russian Federation. (1997). Moscow: Law.

Collection of Legislative Acts of the Russian Federation. (2000). Moscow: Law.

Collection of Legislative Acts of the Russian Federation. (2001). Moscow: Law.

Comment to the legislation about judicial power in the Russian Federation. (2000). Edited by Kashepo. Moscow: Jurid. lit.

Constitutional right of the Russia. (2001). Edited by Malyko. Moscow: Norma.

Gribanov, V. P. (2000). Execution and defense of the civil rights. Moscow: Statut.

Shevchenko, A. S. (1990). Conservative legal relations in the mechanism of defense of subjective civil rights. The mechanism of civil rights defense. Yaroslavl: Nauka.

Skubchenko, L. F. (2000). Constitutional control as the form of judicial defense of the human rights. Moscow: Pravda.

Tikhomirova, L. V. (2001). Juridical encyclopedia. Moscow: Inforgraf. 